\title{
Article \\ Climate Change Effects in a Mediterranean Forest Following 21 Consecutive Years of Experimental Drought
}

\author{
Romà Ogaya $1,2, *(\mathbb{D})$ and Josep Peñuelas ${ }^{1,2}$ (D) \\ 1 CSIC, Global Ecology Unit CREAF-CSIC-UAB, 08193 Bellaterra, Catalonia, Spain; Josep.Penuelas@uab.cat \\ 2 CREAF, 08193 Cerdanyola del Vallès, Catalonia, Spain \\ * Correspondence: r.ogaya@creaf.uab.cat
}

Citation: Ogaya, R.; Peñuelas, J. Climate Change Effects in a Mediterranean Forest Following 21 Consecutive Years of Experimental Drought. Forests 2021, 12, 306. https://doi.org/10.3390/f12030306

Academic Editor: Mariangela Fotelli

Received: 14 January 2021

Accepted: 1 March 2021

Published: 6 March 2021

Publisher's Note: MDPI stays neutral with regard to jurisdictional claims in published maps and institutional affiliations.

Copyright: (c) 2021 by the authors. Licensee MDPI, Basel, Switzerland. This article is an open access article distributed under the terms and conditions of the Creative Commons Attribution (CC BY) license (https:// creativecommons.org/licenses/by/ $4.0 /)$.

\begin{abstract}
Research Highlights: A small, long-term decrease in the water availability in a Mediterranean holm oak forest elicited strong effects on tree stem growth, mortality, and species composition, which led to changes in the ecosystem function and service provision. Background and Objectives: Many forest ecosystems are increasingly challenged by stress conditions under climate change. These new environmental constraints may drive changes in species distribution and ecosystem function. Materials and Methods: An evergreen Mediterranean holm oak (Quercus ilex L.) forest was subjected to 21 consecutive years of experimental drought (performing 30\% of rainfall exclusion resulted in a 15\% decrease in soil moisture). The effects of the annual climatic conditions and the experimental drought on a tree and shrub basal area increment were studied, with a focus on the two most dominant species (Q. ilex and the tall shrub Phillyrea latifolia L.). Results: Stem growth decreased and tree mortality increased under the experimental drought conditions and in hot and dry years. These effects differed between the two dominant species: the basal area of $Q$. ilex (the current, supradominant species) was dependent on water availability and climatic conditions, whereas P. latifolia was more tolerant to drought and experienced increased growth rates in plots where $Q$. ilex decay rates were high. Conclusions: Our findings reveal that small changes in water availability drive changes in species growth, composition, and distribution, as demonstrated by the continuous and ongoing replacement of the current supradominant $Q$. ilex by the subdominant $P$. latifolia, which is better adapted to tolerate hot and dry environments. The consequences of these ecological transformations for ecosystem function and service provision to human society are discussed.
\end{abstract}

Keywords: basal area increment; climate change; forest dieback; Mediterranean forest; stem growth; water availability

\section{Introduction}

Climate change is increasing the levels of environmental stress conditions for many forest ecosystems around the world due to higher rates of evapotranspiration and increases in the intensity and duration of extreme climate events [1,2]. Some water-limited forest ecosystems, such as Mediterranean forests, may be particularly vulnerable to the expected decrease in water availability and may experience associated decreases in stem growth $[3,4]$, greater levels of canopy defoliation [5], and increases in tree mortality [6,7]. While rising concentrations of atmospheric carbon dioxide $\left(\mathrm{CO}_{2}\right)$ are associated with higher growth rates and productivity in forests [8], it is possible that decreases in stem growth may occur in water-limited ecosystems, if the effects of water scarcity exceed those of fertilization from the increasing levels of $\mathrm{CO}_{2}$.

Quercus ilex L. is an evergreen tree species and it is the most abundant and representative of the Mediterranean forest [9]. Phillyrea latifolia L. is a tall shrub evergreen species, and it is also very common in the Mediterranean forest. Both species are well adapted to resist a drought period (usually the summer season) due to their stomatal closure around midday to avoid excessive water loss by transpiration [9]. Despite these two species having 
experienced similar distributions and adaptations for coping with drought conditions, several studies have shown that $Q$. ilex is more sensitive to dry and hot conditions than other co-occurring tall shrub species, such as P. latifolia $[3,4,10,11]$. For example: within a shared forest, $Q$. ilex was found to suffer from high rates of stem mortality during periods of extreme drought, which had little impact on P. latifolia [10,12]; while wood carbon allocation decreased in $Q$. ilex during dry years and remained stable in P. latifolia [11]; and fruit production correlated with annual rainfall in Q. ilex, but not in P. latifolia [11].

Mediterranean vegetation is characterized by the physiological adaptations that allow its tolerance to, and recovery from, episodes of dry environmental conditions; however, if extreme drought events exceed the tipping points of climate tolerance, some sensitive species may fail to survive, whereby species diversity, composition, and associated ecosystem function become permanently altered, leading to perturbations in the ecosystem service provision [13]. Q. ilex is the current dominant species of the Mediterranean forest, and is widely distributed across the whole Mediterranean Basin in South Europe and North Africa, and from Portugal to Syria. Under hotter and drier environmental conditions, a decrease in the abundance of $Q$. ilex in Mediterranean forests may be expected, along with a reduction in forest capacity to mitigate the effects of climate change through the sequestration of atmospheric $\mathrm{CO}_{2}$; there may also be a progressive replacement of $Q$. ilex by other tall shrub species, such as P. latifolia, that transforms the structure and ecosystem function of the forest.

In water-limited ecosystems, the principal effects of hydrological processes on vegetation are mediated through soil water content [14]; thus, experimental methods that affect soil moisture effectively simulate the likely impacts of decreases in water availability on plants. Furthermore, long-term climate manipulation experiments in natural ecosystems allow the prediction of the effects of environmental change on ecosystem function and development $[15,16]$ and may highlight the dampening effect on the size of treatments that has been widely reported in global-change experiments [17].

Here, our main objective was to determine the effects of climate change-mediated drought on the development of the Mediterranean forest, paying special attention to the development of the different species and their possible divergent evolution. This study was conducted as a long-term climate manipulation experiment that simulates a $15 \%$ decrease in soil moisture, as projected by general circulation models for the Mediterranean region [18].

\section{Materials and Methods}

\subsection{Study Site}

The study was conducted in a Mediterranean holm oak forest located on a south facing slope (25\%) of the Prades Mountains, Catalonia, in north-eastern Spain $\left(41^{\circ} 20^{\prime} 38^{\prime \prime} \mathrm{N}\right.$, $1^{\circ} 2^{\prime} 0^{\prime \prime} \mathrm{E}, 950 \mathrm{~m}$ a.s.l.), in which the vegetation comprises dense multi-stem, coppiced woody species (16.616 stems ha $\left.{ }^{-1}\right)$, created for charcoal production; no coppicing activity has taken place in the forest during the preceding 70 years. The dominant species are $Q$. ilex and P. latifolia (both species represent more than $80 \%$ of the total forest basal area). There are also other evergreen shrub species such as Arbutus unedo L., Erica arborea L., and Juniperus oxycedrus L.; deciduous tree species include the occasional Sorbus torminalis L. and Acer monspessulanum L. The soils comprise a Dystric Cambisol, and the range in soil depth $(35$ to $100 \mathrm{~cm}$ ) results in contrasting levels of water and nutrient availability, reflected by two forest-type structures [19]: a tall canopy forest (8-10 $\mathrm{m}$ high) dominated by $Q$. ilex, and a low canopy forest (4-6 m high), with a greater abundance of $P$. latifolia than in tall canopy (Table A1).

\subsection{Experimental Design}

Eight $15 \times 10 \mathrm{~m}$ plots were delimited at the same altitude along the slope (four in the tall canopy stand and another four in the low canopy stand) in 1999. Four of these plots (two each in the tall and low canopy stands) were randomly selected as drought 
plots, and received an experimental partial rainfall exclusion; the four remaining plots were left untreated as a control. In the drought plots, six plastic strips, comprising four rigid PVC tubes connected with transparent PVC, were installed under the canopy along the longitudinal slope, at about $1 \mathrm{~m}$ above the soil surface and extending to $2 \mathrm{~m}$ outside the plot margin to reduce edge-effects; the strips covered $30 \%$ of the plot surface area for the interception of rain throughfall and its removal downslope. Soil moisture was measured monthly using a time domain reflectometer (Delta-T Devices, Cambridge, UK) placed in the upper $15 \mathrm{~cm}$ of the soil profile of four randomly selected loci per plot, along with the leaf water potential (measured seasonally, in two leaves from two different trees per species, collected in the upper layer of the canopy and fully exposed to solar radiation) at the same loci using a Scholander-type chamber pressure (PMS Instrument Company, Albany, OR, USA). An automatic meteorological station installed at the study site monitored temperature and rainfall during the 1999-2019 study period.

\subsection{Basal Area Determination}

In 1999, all of the living tree and shrub stems in the plots were marked at $50 \mathrm{~cm}$ above ground level using permanent paint, and their circumference (diameter $>2 \mathrm{~cm}$ ) was measured at the painted mark annually in winter. The basal area of each stem was determined from the stem circumference measurements, assuming each stem section to be a circle; the annual basal area increment was calculated from the difference in the basal area measured in two consecutive years. For each plot, species, and year, we determined the basal area increment (BAI), basal area lost by stem mortality (BAL), and total basal area increase (TBAI) which was determined as the basal area increment minus basal area lost by stem mortality.

\subsection{Data Analysis}

Seasonal differences in soil moisture and leaf water potential were tested using repeated measures analysis of variance (ANOVA). January, February and March were combined in "winter", April, May and June were combined in "spring", July, August and September were combined in "summer", and October, November and December were combined in "autumn". The relationships between the BAI, BAL, and TBAI per species and canopy stand (dependent variables) and the annual mean temperature, rainfall, and SPEI climatic indices $[3,4,20]$ (independent variables) were tested using linear and polynomial regression analyses. We used general linear modeling to test the determinant factors of the annual BAI, BAL, and TBAI of Q. ilex and P. latifolia. The species, treatment and canopy stand were considered independent factors, and the annual mean temperature and rainfall were covariates. Finally, we conducted the same models without the species factor, and including all tree and shrub species present in the plots named "overall species". All analyses were performed using Statistica 10.0 (StatSoft Inc., 2010, Tulsa, OK, USA).

\section{Results}

\subsection{Soil Moisture and Leaf Water Potential}

The meteorological conditions of the study site were typically Mediterranean: summers were hot and dry, winters were relatively cold, and rainfall events tended to be concentrated in spring and autumn (Figure 1). Accordingly, both soil moisture and leaf water potential levels showed a clear seasonality; their values decreased in summer, recovered in autumn, and were greatest in spring and winter when evapotranspiration rates were lower. Soil moisture levels were $15 \%$ lower in the drought plots than in the control plots $(p<0.05)$ (Figure 2). The decrease in leaf water potential values in summer was stronger in P. latifolia than in $Q$. ilex $(p<0.05)$, whereas in autumn, $Q$. ilex maintained a higher water potential than P. latifolia; in winter and spring, the levels were similar in both species (Figure 2). The drought treatment did not exert any significant additional effect on the leaf water potential levels. 


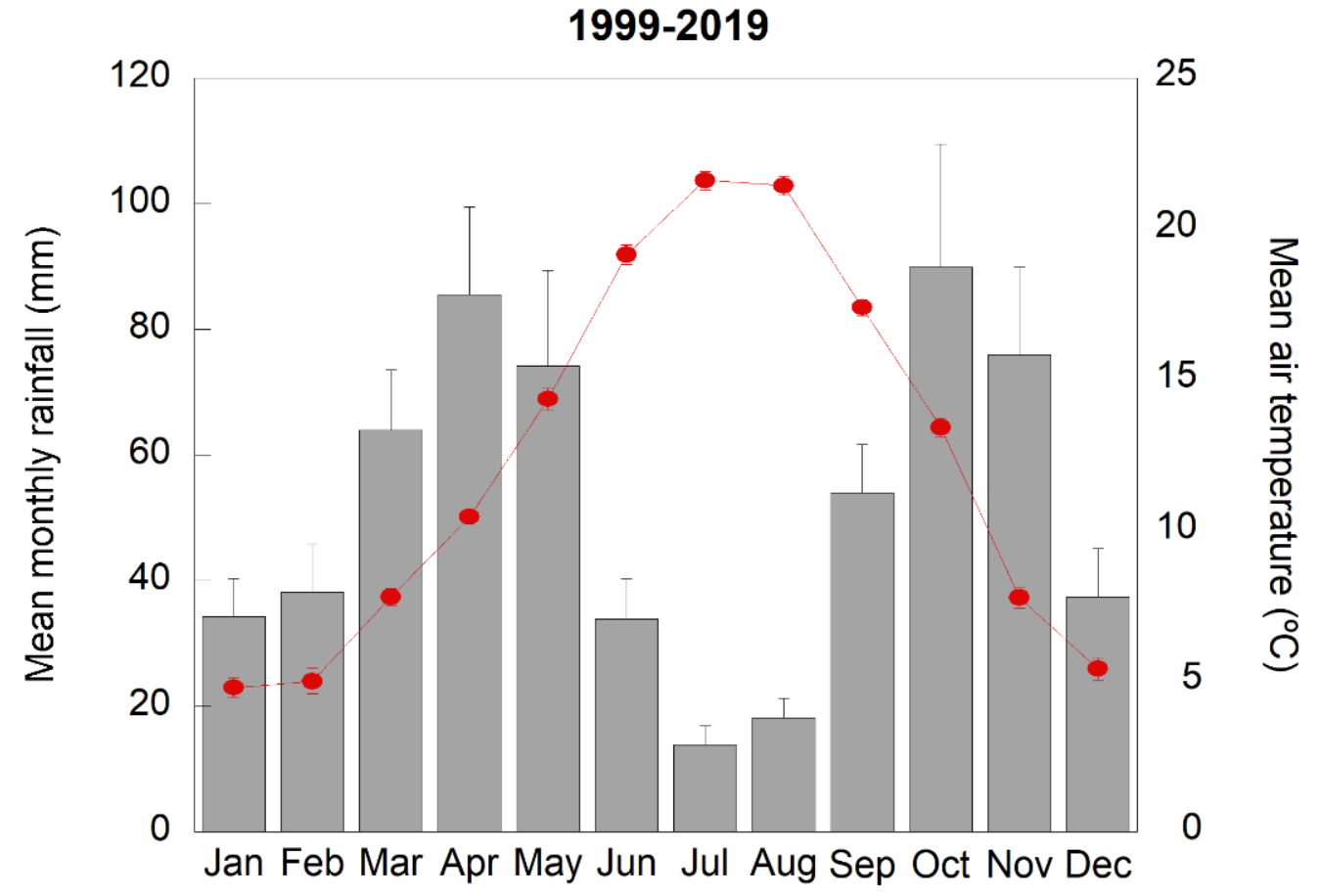

Figure 1. Average meteorological conditions at the study site during the experimental period (1999-2019). Red dots indicate mean monthly air temperature and grey columns indicate mean monthly rainfall. Vertical bars in the grey columns and red dots indicate the standard error of the mean ( $n=21$ years).
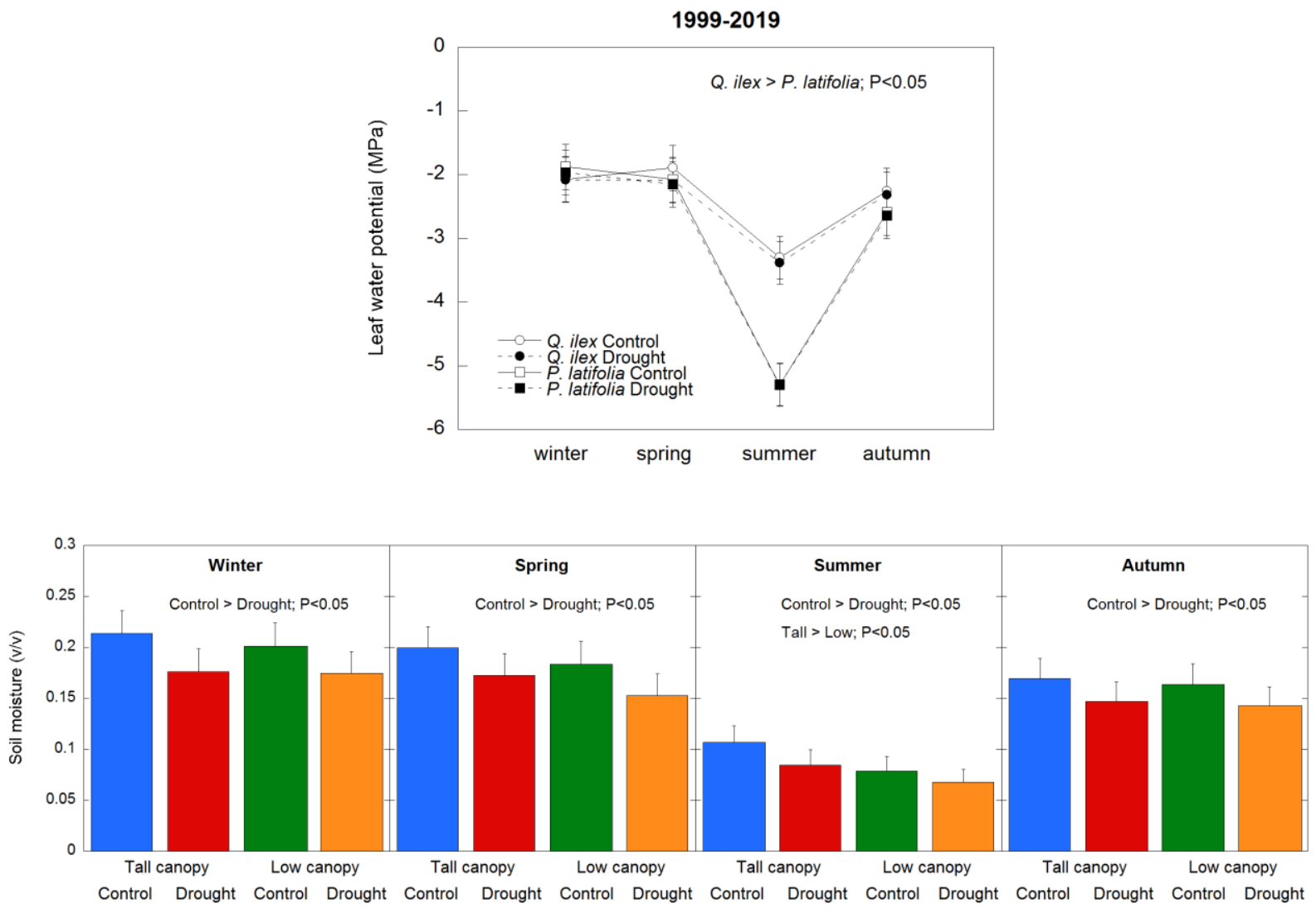

Figure 2. Average seasonal leaf water potential (upper panel) and soil moisture (lower panel) during the study period (1999-2019). Vertical bars indicate the standard error of the mean ( $n=21$ years). 


\subsection{Climate Effects on Stem Growth}

BAI was positively related to the annual rainfall in the two species separately ( $Q$. ilex: $p<0.05$; P. latifolia: $p<0.01)$ and for all of the tree and shrub species $(p<0.01)$ (Figure 3); there was a trend towards a positive relationship between the BAL and the mean annual temperature in $Q$. ilex $(p=0.06)$ and all of the tree and shrub species $(p=0.06)$, but not in P. latifolia (Figure 4). As a consequence of lower stem growth in dry years and greater stem mortality in hot years, the TBAI was positively related to the annual rainfall in $Q$. ilex $(p=0.05)$, P. latifolia $(p<0.01)$, and all of the tree and shrub species $(p<0.01)$, but these relationships were not linear; they tended to saturate at high precipitation values. On the other hand, there was a negative relationship between the TBAI and the mean annual temperature in $Q$. ilex $(p=0.05)$ and all of the tree and shrub species $(p<0.05)$; in P. latifolia, there was a trend towards a negative relationship between the TBAI and the mean annual temperature $(p=0.06)$. Also, these relationships were not linear; they tended to increase at very low temperature values, but strongly decrease at high temperatures. Thes effects of climate on stem growth differed between the two canopy stands, where the mean annual temperature tended to be more determinant for the TBAI in the tall canopy stand for $Q$. ilex $(p<0.05)$ and all of the tree and shrub species together $(p<0.05)$, whereas the annual rainfall was more determinant for the TBAI in the low canopy stand for $Q$. ilex $(p=0.05)$, P. latifolia $(p<0.01)$ and all of the tree and shrub species together $(p<0.05)$ (Figure 5). However, we did not obtain significative results between the BAI measurements and SPEI climatic indices.
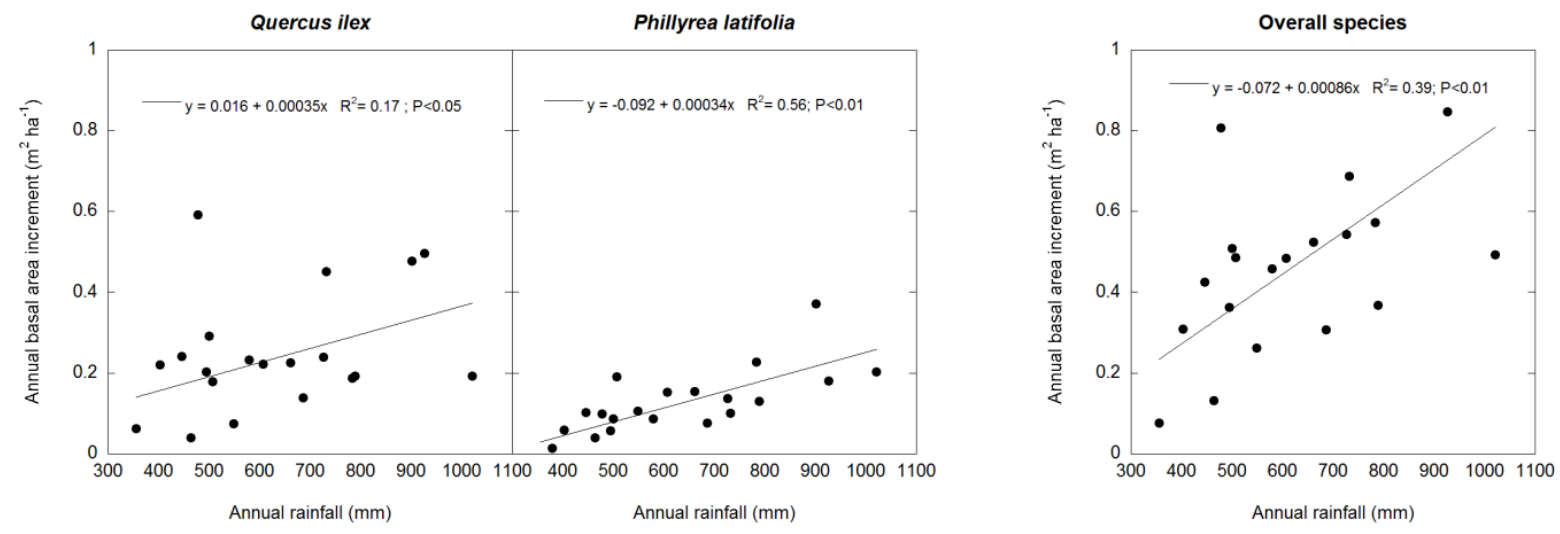

Figure 3. Linear regression analysis of annual basal area increment (BAI) and annual rainfall in Q. ilex, P. latifolia, and all tree and shrub species. $n=21$ years.
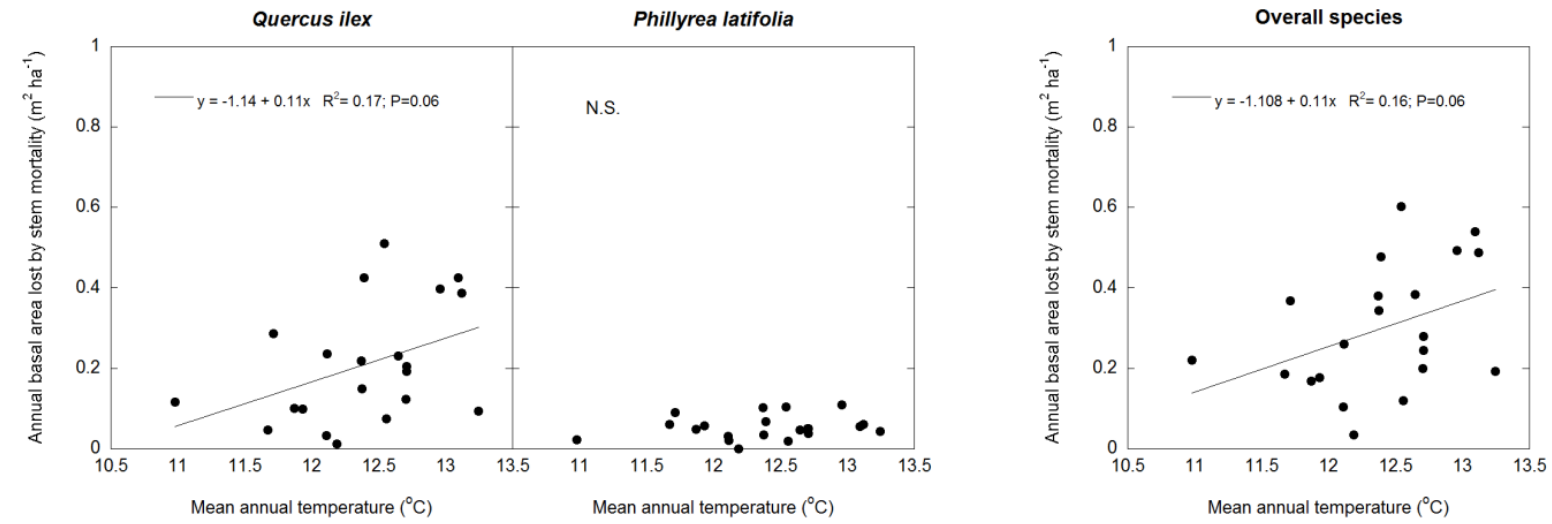

Figure 4. Linear regression analysis of annual basal area lost by stem mortality (BAL) and mean annual temperature in $Q$. ilex, P. latifolia, and all tree and shrub species. $n=21$ years. 

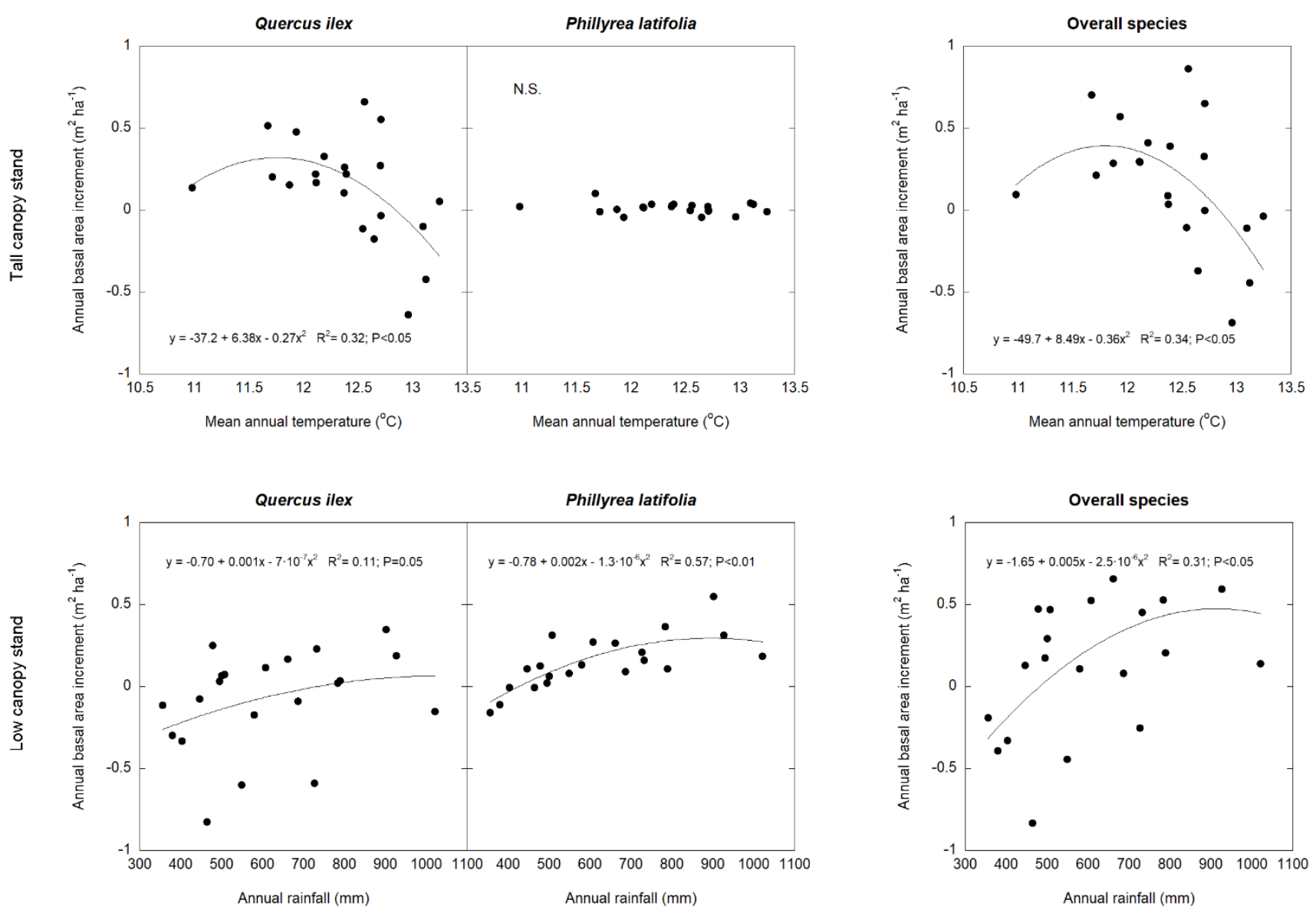

Figure 5. Polynomial regression analysis of total annual basal area increase (TBAI) and mean annual temperature in the tall canopy stand and total annual rainfall in the low canopy stand, for Q. ilex, P. latifolia, and all of the tree and shrub species. $n=21$ years.

\subsection{Drought Effects on Stem Growth}

Between 1999 and 2019, regardless of treatment, the BAI in Q. ilex was greater in the tall canopy stand than in the low canopy stand, while in P. latifolia it was lower in the tall canopy stand than in the low canopy stand (species $\times$ canopy interaction: $F=114.1$, $p<0.01$ ), reflecting the recorded basal area of the species in 1999 and 2019 (Table A1); there was no difference in the BAI between the tall and low canopy stands when all of the tree and shrub species were considered together (Figure 6). While there were no effects of the drought on the BAI in Q. ilex, P. latifolia, or all of the tree and shrub species, the BAL was greater in the drought plots in $Q$. ilex and P. latifolia $(F=8.4, p<0.01)$, and all of the tree and shrub species $(F=8.1, p<0.01)$, with no overall BAL canopy type differences in $Q$. ilex or all of the tree and shrub species. In P. latifolia, the BAL was greater in the low canopy stand (Figure 6); however, the BAL was always higher in Q. ilex than in P. latifolia ( $F=33.9$, $p<0.01)$. Across the study period, the TBAI reflected clear differences between the two species: Q. ilex experienced a higher TBAI in the tall canopy stand, whereas P. latifolia experienced higher TBAI in low canopy stand (species $\mathrm{x}$ canopy interaction: $F=29.1$, $p<0.01)$; there was also a clear decrease in the TBAI levels induced by drought $(F=5.7$, $p=0.02$ ), especially in $Q$. ilex (species $\mathrm{x}$ treatment interaction: $F=5.1, p=0.02$ ). We found that the maximum TBAI in $Q$. ilex was recorded in non-restricted rainfall (control) plots located in the tall canopy stand, where there was a slight positive association between the TBAI and drought treatment in the tall canopy stand and a slight negative association between the TBAI and non-restricted rainfall in the low canopy stand; the lowest TBAI was recorded in drought plots of the low canopy stand (Figure 7). When all of the tree and 
shrub species were considered together, there was a decrease in the TBAI levels in drought plots $(F=12.9, p<0.01)$ and there was no difference in the canopy stand type (Figure 7$)$.

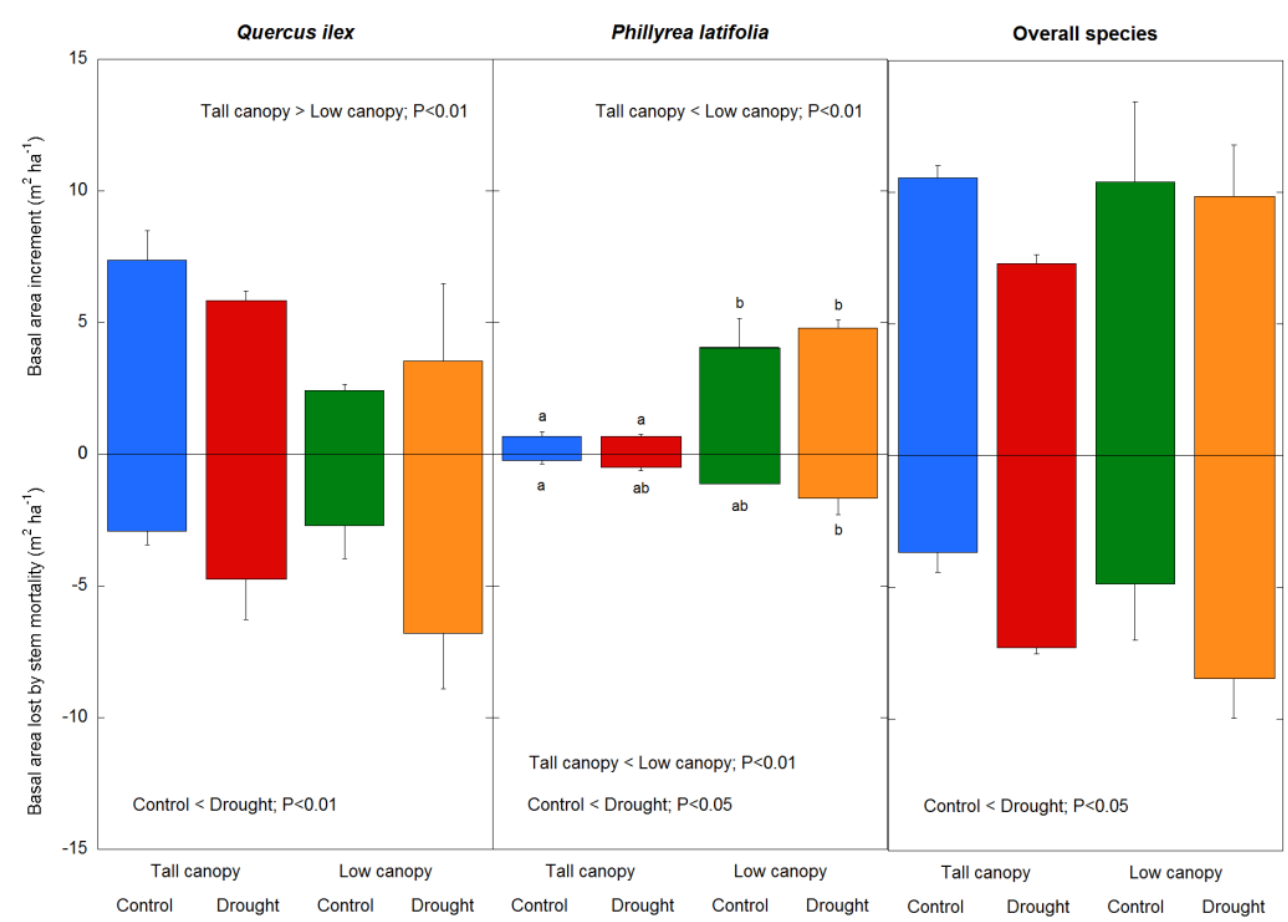

Figure 6. Drought treatment and canopy stand type effects on basal area increment (BAI) and basal area lost by stem mortality (BAL) in Q. ilex, P. latifolia, and all of the tree and shrub species during the study period (1999-2019). Vertical bars indicate the standard error of the mean ( $n=21$ years). Different letters indicate drought treatment differences between and within the canopy stand types $(p<0.05)$.

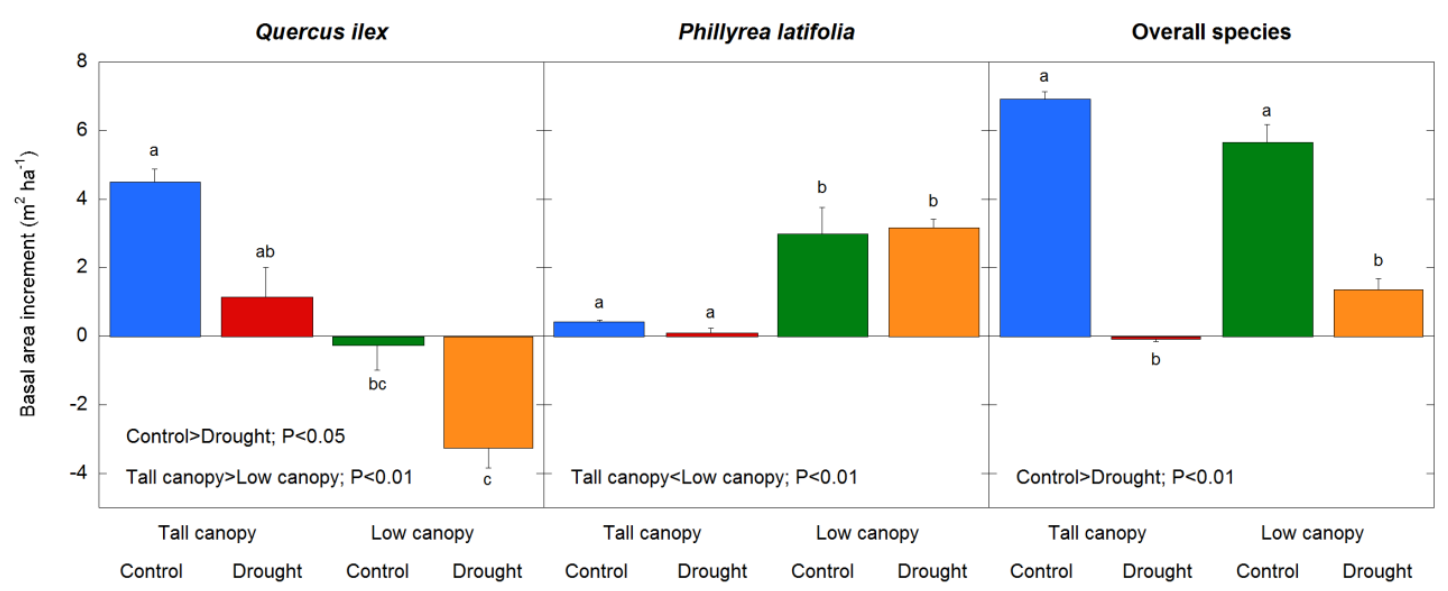

Figure 7. Drought treatment and canopy stand type effects on total basal area increment (TBAI) in Q. ilex, P. latifolia, and all of the tree and shrub species during the study period (1999-2019). Vertical bars indicate the standard error of the mean ( $n=21$ years). Different letters indicate drought treatment differences between and within the canopy stand types $(p<0.05)$.

Overall, the TBAI of the most representative species of the study forest followed three main response patterns to changes in soil moisture: species with a greater TBAI under non-drought conditions, such as Q. ilex, A. unedo, and J. oxycedrus; species with a similar TBAI, regardless of drought conditions, such as P. latifolia, E. arborea, and Rhamnus alaternus; and species with decreases in the TBAI, regardless of drought conditions, albeit with larger decreases under drought conditions, such as S. torminalis (Figure 8). 


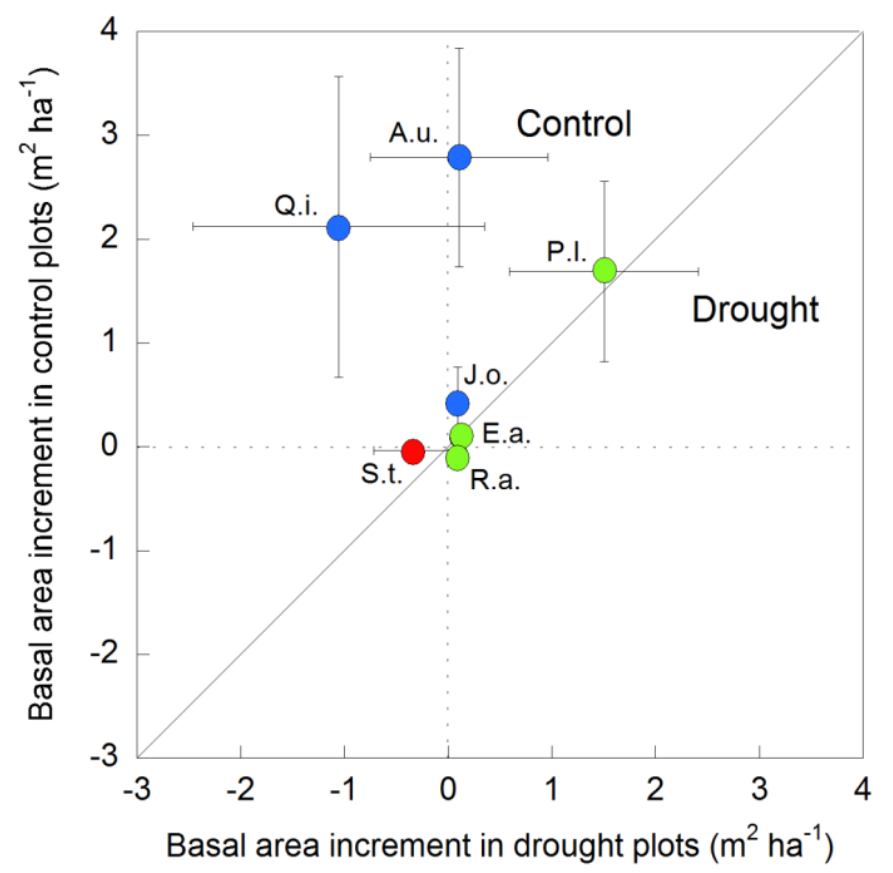

Figure 8. Total basal area increment (TBAI) of the most representative forest tree and shrub species under full (control) and partial (drought) rainfall conditions during the study period (1999-2019). Vertical and horizontal bars indicate the standard error of the mean $(n=21$ years). Species with a higher TBAI in control plots than in drought plots are depicted with blue circles, species with a similar TBAI in both control and drought plots are depicted with green circles, and the species with a negative TBAI in both the control and drought plots are depicted with a red circle. Q.i. means Quercus ilex, A.u. means Arbutus unedo, J.o. means Juniperus oxycedrus, P.1. means Phillyrea latifolia, E.a. means Erica arborea, R.a. means Rhamnus alaternus, and S.t. means Sorbus torminalis.

\section{Discussion}

As observed previously at this experimental study site $[3,4,12,20]$, we found that the tree and shrub stem growth was constrained by water availability and tree mortality increased in dry and hot years. These effects were particularly marked in the dominant species, Q. ilex, whereas in other species, such as P. latifolia, that are more tolerant of lower levels of water availability, there were no effects of experimental drought and there was positive stem growth, especially where the $Q$. ilex abundance was declining in the droughted low canopy stand. Many studies report an increase in basal area increment with tree size [21], and a different climate sensitivity depending on tree size [22], but the $Q$. ilex stem size tended to be greater than that of P. latifolia. Despite this, the BAI was lower in Q. ilex than in P. latifolia, and in the low canopy stand where the tree size of both of the species was similar, climate sensitivity was higher in $Q$. ilex than in P. latifolia. These two species share a strategy to avoid excessive water loss due to transpiration; they close their stomata when they are subjected to a high vapor pressure deficit and low water availability. However, previous findings from this long-term experiment revealed only a small decrease in net photosynthetic $\mathrm{CO}_{2}$ uptake induced by the drought treatment in the two species; this small reduction in the photosynthetic rate is insufficient to explain the considerable decrease in the BAI observed in Q. ilex from the drought plots [23]. Changes in the leaf water potential and other physiological parameters may explain the lower BAI in droughted Q. ilex in this study; for example, lower production of new leaves in Q. ilex canopies has been recorded under drought conditions than under control conditions, with no such treatment differences in the P. latifolia leaf demography [24].

We found that the experimental drought increased stem mortality in all of the tree and shrub species, but this effect was stronger in Q. ilex than in P. latifolia. Increases in both the air temperature and dry conditions are considered to be the most important drivers of tree 
mortality due to hydraulic failure and carbon starvation $[6,7,25]$. In our study, mortality increased markedly with the mean annual temperature in Q. ilex, whereas P. latifolia was more tolerant of higher temperatures, as indicated by the similar mortality rates across the study years [12]. Despite their similar physiological strategies to increase tolerance of dry conditions, detailed xylem architecture observations revealed wider xylem vessels in Q. ilex than in P. latifolia [26] that allow the transport of greater amounts of sap under well-watered conditions, but are more susceptible to embolism under drought conditions.

Shifts in species distributions induced by climate change are expected to occur globally in several biomes $[27,28]$. Across the duration of this long-term experiment, the total basal area of $Q$. ilex decreased exponentially with an increase in air temperature and decrease in rainfall, while a previous study showed the contrasting presence of abundant $P$. latifolia seedlings and young individuals and scarce $Q$. ilex seedlings in this forest [29], indicating that the replacement of moribund $Q$. ilex may only be possible from resprouting shoots. These results indicate that the warming air temperatures and decreasing water availability that are predicted for the Mediterranean Basin [1] will lead to a receding $Q$. ilex distribution and progressive substitution by shrub species better adapted to drier conditions, particularly under extreme arid conditions, such as those in the low canopy stand. By the first time, we detected in our experimental site a clear substitution of $Q$. ilex by other shrub species, as it was clearly observed in the low canopy stand.

Across the study period, the total basal area of the drought plots did not increase, and this reduction in plant productivity was accompanied by other important changes in the ecosystem function of the forest. For example: leaf material from the drought treatment contained greater concentrations of nitrogen $(\mathrm{N})-15$ than that from the control, due to greater ecosystem $\mathrm{N}$ losses under the experimental drought conditions [30]; bacteria diversity has been shown to be particularly sensitive to water availability and fungi diversity was more tolerant to seasonal and experimental changes in soil moisture [31]; and drought conditions led to decreases in soil phosphatase activity [32] and altered trophic interactions, such as increases in leaf sugar and phenol concentrations to resist drier conditions, that boosted levels of insect herbivory [19].

In order to increase ecosystem contributions to climate change mitigation, considerable efforts have been made to preserve species composition and the associated ecosystem function and service provision [33]. For Mediterranean forests, such as that studied here, with high levels of stem density and competition and an associated low BAI [34], the reduction of stem density by selective thinning may represent an appropriate management option to improve the BAI [12,35].

\section{Conclusions}

The results from this long-term study demonstrated a progressive replacement of the dominant species, Q. ilex, by another shrub species, P. latifolia, that was better adapted to the hotter and drier climatic conditions that are predicted to impact this Mediterranean region over the coming decades. The slight decrease in water availability, as simulated by the drought treatment, that reduced soil moisture by $15 \%$ exacerbated this transition in relative species abundance and contributed to a decrease in stem growth and an increase in tree mortality in Q. ilex. The experimental drought also elicited additional, ecosystem level impacts, including losses in $\mathrm{N}$, changes in the metabolic activity of soil organisms, and the capacity to resist attack by plant pathogens. Importantly, some ecosystem services of this forest type, such as the amelioration of climate change impacts as a carbon sink, are expected to decline further with the ongoing and continued changes in the climate.

Author Contributions: Conceptualization, experimental design, statistical analyses, and discussion of the results: R.O. and J.P.; writing: R.O.; and, supervision: J.P. All authors have read and agreed to the published version of the manuscript. 
Funding: This research was financially supported by the Spanish government project PID2019110521GB-I00 ELEMENTAL SHIFT, the European Research Council Synergy grant ERC-2013-SyG2013-610028 IMBALANCE-P, and the Catalan government grant SGR-2017-1005.

Acknowledgments: This study was undertaken with the approval of Ester Trullols, director of the PNIN de Poblet Natural Park.

Conflicts of Interest: The authors declare no conflict of interest.

\section{Appendix A}

Table A1. Mean ( \pm SEM) basal area $\left(\mathrm{m}^{2} \mathrm{ha}^{-1}\right)$ of $Q$. ilex, P. latifolia, and all tree and shrub species in the plot types at the start and the end of the study period (1999-2919) ( $n=2$ plots).

\begin{tabular}{cccc}
\hline Species & Plot Type & Basal Area 1999 & Basal Area 2019 \\
\hline Overall Species & Tall control & $45.83 \pm 2.89$ & $52.74 \pm 2.58$ \\
Overall Species & Tall drought & $48.68 \pm 3.87$ & $48.64 \pm 4.02$ \\
Overall Species & Low control & $39.19 \pm 9.37$ & $44.79 \pm 10.18$ \\
Overall Species & Low drought & $33.25 \pm 9.39$ & $34.59 \pm 9.86$ \\
Quercus ilex & Tall control & $37.70 \pm 3.67$ & $42.18 \pm 4.24$ \\
Quercus ilex & Tall drought & $37.94 \pm 4.91$ & $39.08 \pm 3.68$ \\
Quercus ilex & Low control & $15.99 \pm 4.92$ & $15.75 \pm 3.87$ \\
Quercus ilex & Low drought & $19.03 \pm 12.14$ & $15.78 \pm 12.97$ \\
Phillyrea latifolia & Tall control & $2.19 \pm 1.14$ & $2.61 \pm 1.23$ \\
Phillyrea latifolia & Tall drought & $2.88 \pm 0.48$ & $2.94 \pm 0.23$ \\
Phillyrea latifolia & Low control & $15.24 \pm 3.37$ & $18.20 \pm 4.49$ \\
Phillyrea latifolia & Low drought & $13.21 \pm 2.65$ & $16.36 \pm 2.29$ \\
\hline
\end{tabular}

\section{References}

1. Allen, M.R.; Babiker, M.; Chen, Y.; de Coninck, H.; Connors, S.; van Diemen, R.; Dube, O.P.; Ebi, K.L.; Engelbrecht, F.; Ferrat, M.; et al. IPCC 2018: Summary of Policymakers. In Global Warming of $1.5^{\circ} \mathrm{C}$. An IPCC Special Report on the Impacts of Global Warming of $1.5{ }^{\circ} \mathrm{C}$ Above Pre-Industrial Levels and Related Global Greenhouse Gas Emission Pathways, in the Context of Strengthening the Global Response to the Threat of Climate Change, Sustainable Development, and Efforts to Eradicate Poverty; Masson-Delmotte, V., Pörtner, H.O., Skea, J., Zhai, P., Roberts, D., Shukla, P.R., Pirani, A., Moufouma-Okia, W., Péan, C., Pidcock, R., et al., Eds.; World Meteorological Organization: Geneva, Switzerland, 2018; p. 32.

2. Wang, W.; Peng, C.; Kneeshaw, D.D.; Larocque, G.R.; Luo, Z. Drought induced tree mortality: Ecological consequences, causes, and modeling. Environ. Rev. 2012, 20, 109-121. [CrossRef]

3. Barbeta, A.; Ogaya, R.; Peñuelas, J. Dampening effects of long-term experimental drought on growth and mortality rates of a Holm oak forest. Glob. Chang. Biol. 2013, 19, 3133-3144. [CrossRef]

4. Liu, D.; Ogaya, R.; Barbeta, A.; Yang, X.; Peñuelas, J. Long-term experimental drought combined with natural extremes accelerate vegetation shift in a Mediterranean holm oak forest. Environ. Exp. Bot. 2018, 151, 1-11. [CrossRef]

5. Carnicer, J.; Coll, M.; Ninyerola, M.; Pons, X.; Sanchez, G.; Peñuelas, J. Widespread crown condition decline, food web disruption, and amplified tree mortality with increased climate change-type drought. Proc. Natl. Acad. Sci. USA 2011, 108, 1474-1478. [CrossRef]

6. Allen, C.D.; Macalady, A.K.; Chenchouni, H.; Bachelet, D.; McDowell, N.; Vennetier, M.; Kitzberger, T.; Rigling, A.; Breshears, D.D.; Hogg, E.H.; et al. A global overview of drought and heat-induced tree mortality reveals emerging climate change risks for forests. For. Ecol. Manag. 2010, 259, 660-684. [CrossRef]

7. Breshears, D.D.; Cobb, N.S.; Rich, P.M.; Price, K.D.; Allen, C.D.; Balice, R.G.; Romme, W.H.; Kastens, J.H.; Floyd, M.L.; Belnap, J.; et al. Regional vegetation die-off in response to global-change-type drought. Proc. Natl. Acad. Sci. USA 2005, 102, 15144-15148. [CrossRef] [PubMed]

8. Moore, D.J.P.; Aref, S.; Ho, R.M.; Pippen, J.S.; Hamilton, J.G.; de Lucia, E.H. Annual basal area increment and growth duration of Pinus taeda in response to eight years of free-air carbon dioxide enrichment. Glob. Chang. Biol. 2006, 12, 1367-1377. [CrossRef]

9. Terradas, J. Holm oak and holm oak forests: An introduction. In Ecology of Mediterranean Evergreen oak Forests; Rodà, F., Retana, J., Gracia, C.A., Bellot, J., Eds.; Springer: Berlin, Germany, 1999; pp. 3-14.

10. Peñuelas, J.; Filella, I.; Llusià, J.; Siscart, D.; Piñol, J. Comparative field study of spring and summer leaf gas Exchange and photobiology of the Mediterranean trees Quercus ilex and Phillyrea latifolia. J. Exp. Bot. 1998, 49, 229-238. [CrossRef]

11. Ogaya, R.; Penuelas, J. Wood vs. canopy allocation of aboveground net primary productivity in a Mediterranean forest during 21 years of experimental rainfall exclusion. Forests 2020, 11, 1094. [CrossRef] 
12. Ogaya, R.; Liu, D.; Barbeta, A.; Peñuelas, J. Stem Mortality and Forest Dieback in a 20-Years Experimental Drought in a Mediterranean Holm Oak Forest. Front. For. Glob. Chang. 2020, 2, 89. [CrossRef]

13. Peñuelas, J.; Sardans, J.; Filella, I.; Estiarte, M.; Llusià, J.; Ogaya, R.; Carnicer, J.; Bartrons, M.; Rivas-Ubach, A.; Grau, O.; et al. Impacts of global change on Mediterranean forests and their services. Forests 2017, 8, 463. [CrossRef]

14. Yin, J.; D'Odorico, P.; Porporato, A. Soil Moisture Dynamics in Water-Limited Ecosystems. In Dryland Ecohydrology; D’Odorico, P., Porporato, A., Wilkinson Runyan, C., Eds.; Springer: Cham, Switzerland, 2019; pp. 31-48.

15. Kröel-Dulay, G.; Ransijn, J.; Schmidt, I.K.; Beier, C.; de Angelis, P.; de Dato, G.; Dukes, J.S.; Emmett, B.A.; Estiarte, M.; Garadnai, J.; et al. Increased sensitivity to climate change in disturbed ecosystems. Nat. Comm. 2015, 1-7. [CrossRef]

16. Liu, D.; Zhang, C.; Ogaya, R.; Estiarte, M.; Peñuelas, J. Effects of decadal experimental drought and climate extremes on vegetation growth in Mediterranean forests and shrublands. J. Veg. Sci. 2020, 31, 768-779. [CrossRef]

17. Leuzinger, S.; Luo, Y.; Beier, C.; Dieleman, W.; Vicca, S.; Körner, C. Do global change experiments overestimate impacts on terrestrial ecosystems? Trends Ecol. Evol. 2011, 26, 236-241. [CrossRef]

18. Bates, B.C.; Kundzewicz, Z.W.; Wu, S.; Palutikof, J.P. Climate Change and Water. Technical Paper of the Intergovernmental Panel on Climate Change; IPCC Secretariat: Geneva, Switzerland, 2018; p. 210.

19. Rivas-Ubach, A.; Gargallo-Garriga, A.; Sardans, J.; Oravec, M.; Mateu-Castell, L.; Pérez-Trujillo, M.; Parella, T.; Ogaya, R.; Urban, O.; Peñuelas, J. Drought enhances folivory by shifting foliar metabolomes in Quercus ilex trees. New Phytol. 2014, 202, 874-885. [CrossRef]

20. Ogaya, R.; Barbeta, A.; Basnou, C.; Peñuelas, J. Satellite data as indicators of tree biomass growth and forest dieback in a Mediterranean holm oak forest. Ann. For. Sci. 2015, 72, 135-144. [CrossRef]

21. Stephenson, N.L.; Das, A.J.; Condit, R.; Russo, S.E.; Baker, P.J.; Beckman, N.G.; Coomes, D.A.; Lines, E.R.; Morris, W.K.; Rüger, N.; et al. Rate of tree carbon accumulation increases continuously with tree size. Nature 2014, 507, 90-93. [CrossRef]

22. Trouillier, M.; van der Maaten-Theunissen, M.; Scharnweber, T.; Würth, D.; Burger, A.; Schnittler, M.; Wilmking, M. Size matters-a comparison of three methods to assess age- and size-dependent climate sensitivity of trees. Trees 2019, 33, 183-192. [CrossRef]

23. Ogaya, R.; Llusià, J.; Barbeta, A.; Asensio, D.; Liu, D.; Alessio, G.A.; Peñuelas, J. Foliar $\mathrm{CO}_{2}$ in a holm oak forest subjected to 15 years of climate change simulation. Plant Sci. 2014, 226, 101-107. [CrossRef] [PubMed]

24. Ogaya, R.; Peñuelas, J. Contrasting foliar responses to drought in Quercus ilex and Phillyrea latifolia. Biol. Plant. 2006, 50, 373-382. [CrossRef]

25. Sevanto, S.; McDowell, N.G.; Dickman, L.T.; Pangle, R.; Pockman, W.T. How do trees die? A test of the hydraulic failure and carbon starvation hypotheses. Plant Cell Environ. 2014, 37, 153-161. [CrossRef] [PubMed]

26. Martínez-Vilalta, J.; Prat, E.; Oliveras, I.; Piñol, J. Hydraulic properties of roots and stems of nine woody species from a Holm oak forest in NE Spain. Oecologia 2002, 133, 19-29. [CrossRef] [PubMed]

27. Wu, Z.; Dijskstra, P.; Koch, G.W.; Peñuelas, J.; Hungate, B.A. Responses of terrestrial ecosystems to temperature and precipitation change: A meta-analysis of experimental manipulation. Glob. Chang. Biol. 2011, 17, 927-942. [CrossRef]

28. Peñuelas, J.; Sardans, J.; Filella, I.; Estiarte, M.; Llusià, J.; Ogaya, R.; Carnicer, J.; Bartrons, M.; Rivas-Ubach, A.; Grau, O.; et al. Assessment of the impacts of climate change on Mediterranean terrestrial ecosystems based on data from field experiments and long-term monitored field gradients in Catalonia. Env. Exp. Bot. 2018, 152, 49-59.

29. Lloret, F.; Peñuelas, J.; Ogaya, R. Seedling versus sprout recruitment of two Mediterranean trees (Phillyrea latifolia and Quercus ilex) under drought conditions. J. Veg. Sci. 2004, 15, 237-244. [CrossRef]

30. Ogaya, R.; Peñuelas, J. Changes in leaf $\delta^{13} \mathrm{C}$ and $\delta^{15} \mathrm{~N}$ and trunk growth for three Mediterranean tree species in relation to soil water availability. Acta Oecol. 2008, 34, 331-338. [CrossRef]

31. Curiel-Yuste, J.; Peñuelas, J.; Estiarte, M.; Garcia-Mas, J.; Mattana, S.; Ogaya, R.; Pujol, M.; Sardans, J. Drought-resistant fungi control soil organic matter decomposition and its response to temperature. Glob. Chang. Biol. 2011, 17, 1475-1486. [CrossRef]

32. Sardans, J.; Peñuelas, J.; Ogaya, R. Experimental drought reduced acid and alkaline phosphatise activity and increased organic extractable P in soil in a Quercus ilex Mediterranean forest. Eur. J. Soil Biol. 2008, 44, 509-520. [CrossRef]

33. Ingrisch, J.; Bahn, M. Towards a comparable quantification of resilience. Trends Ecol. Evol. 2018, 33, 251-259. [CrossRef] [PubMed]

34. Vospernik, S. Basal area increment models accounting for climate and mixture for Austrian tree species. For. Ecol. Manag. 2021, 480, 118725. [CrossRef]

35. Martín-Benito, D.; Rio, M.; Heinrich, I.; Helle, G.; Cañellas, I. Response of climate-growth relationships and water use efficiency to thinning in a Pinus nigra afforestation. For. Ecol. Manag. 2010, 259, 967-975. [CrossRef] 